\title{
Population dynamics of pink stem borer, Sesamia inferens (Walker) on maize as influenced by weather conditions
}

\author{
Hemant Sharma*, M. S. Jaglan and S. S. Yadav \\ Department of Entomology, CCS Haryana Agricultural University, Hisar-125004 (Haryana), INDIA \\ *Corresponding author. E-mail: sharmahemant0608@gmail.com \\ Received: December 24, 2016; Revised received: April 14, 2017; Accepted: September 15, 2017
}

\begin{abstract}
A field study on population dynamics of pink stem borer, Sesamia inferens (Walker) on maize was carried out during rabi, 2015-2016 at the research farm of CCS Haryana Agricultural University, Regional Research Station, Karnal. Studies on population dynamics revealed that the maximum number of egg masses was observed during $46^{\text {th }} \mathrm{SW}$ (standard week), 2015. The larval population increased after $45^{\text {th }} \mathrm{SW}$ and reached the maximum during the $49^{\text {th }} \mathrm{SW}, 2015$ and then declined till $7^{\text {th }} \mathrm{SW}, 2016$. Maximum plant infestation by larvae was recorded 19.5 per cent in inbred HKI 1128 and 21.0 per cent in hybrid HQPM 1 during the $7^{\text {th }} \mathrm{SW}, 2016$. No larval activity of $S$. inferens, plant infestation and dead hearts were observed during $2^{\text {nd }} \mathrm{SW}$ to $4^{\text {th }} \mathrm{SW}$ of 2016 (second week to last week of January). It could be due to the fact that insect might have entered the hibernation. Correlation of $S$. inferens population with various environmental factors revealed that larval population had a significant negative correlation with maximum temperature (Tmax.) and minimum temperature (Tmin.), rainfall (RF) ( $r=-0.4992,-0.5183$ and -0.5698$)$ on $\mathrm{HKI}$ 1128 and $(r=-0.4872,-0.4717$ and -0.5242$)$ on HQPM 1, respectively. Multiple regression analysis of $S$. inferens population with weather parameters showed that there was 80 per cent (HQPM1) and 82 per cent (HKI 1128) variability in larval population due to various environmental factors. The population dynamics revealed by this study have far reaching significance in pest management strategy as integrated control measures may be focused only during the period wherein population exceeds economic threshold level (ETL).
\end{abstract}

Keywords: Population dynamics, Sesamia inferens, Maize, Weather conditions

\section{INTRODUCTION}

Maize (Zea mays L.) is one of the most important cereal crops of the world and contributes to food security in most of the developing countries. It is cultivated over a range of agro climatic zones and the suitability of maize to diverse environments is unmatched by any other crop. It is grown in more than 150 countries but the major producing countries are USA, China, Brazil, Mexico, France and India. It can be used at any stage of its growth and has over three thousand industrial uses. In India, maize is cultivated throughout the year in all states of the country for various purposes including grain, fodder, green cobs, sweet corn, baby corn and popcorn. Maize is important in human nutrition and also used as animal feed. It can be cultivated throughout the year in different seasons (kharif, rabi and spring) in one or the other part of the country. The demand of the maize is increasing every day due to expansion of maize based industries. It is third important cereal crop in India after rice and wheat and occupies an area of 8.78 million hectares having production of 21.76 million tones with average productivity of $2.48 \mathrm{t} /$ ha (Anonymous, 2014). The average productivity is very low in comparison to its potential. Since the gap between the productivity and the poten- tial is very wide, there is tremendous scope for the management of crop production/ protection practices. Pink stem borer, $S$. inferens is one of the major insect pests of maize next to Chilo partellus. S. inferens is a serious pest of maize in India, Pakistan, Bangladesh, Burma, China, Sri Lanka, Malaysia, Taiwan, Japan, Indonesia, and the Philippines (Teetes et al., 1983). In India, it is a major pest in Andra Pradesh, Karnatka, Tamil Nadu, Maharastra, Uttar Pradesh, Assam, Bihar, Delhi, Punjab, Orrisa, Madhya Pradesh, West Bengal and Andaman and Nicobar (Rajagopal and Channabasavanna, 1975; Bhattacharya, 1976; Sajjan et al., 1986; Upadhyaya et al, 1991). Recently, S. inferens has emerged as a new pest and is likely to pose serious threat to the successful cultivation of maize in the north-western plains of India under largely adopted rice-wheat/maize cropping system (Singh and Kular, 2015). It attacks and damages every part of maize except root. Yield loss is mainly due to dead heart formation in maize crop (Siddiqui and Marwaha, 1993). In India, the losses due to pink stem borer on maize are reported to be varied from 25.7 to 78.9 percent (Chatterji et al., 1969) and 25 to 80 per cent (Rao et al., 1983). S. inferens is an emerging pest in Haryana and causes economic damage to the production of maize during rabi season. It is a polyphagous pest and 
a considerable population of this pest migrates from paddy and wheat crops to winter maize. The incidence of $S$. inferens is on an increasing trend and may be a threat to winter maize cultivation. A thorough knowledge of population dynamics in relation to biotic, abiotic factors of an insect-pest is essential for developing efficient pest management strategies. The information on population dynamics of any insect pest in a given ecological niche should be considered as starting point for evolving eco- friendly pest management strategies. It is an established fact that population dynamics of any insect is greatly influenced by weather fluctuations and thereby the location specific studies become more imperative. It was with this in mind that the present study was carried out to investigate population dynamics of pink stem borer, $S$. inferens on maize as influenced by weather conditions.

\section{MATERIALS AND METHODS}

This study pertaining to population dynamics of pink stem borer, Sesamia inferens (Walker) on maize was carried out during rabi, 2015-2016 at research area of CCS Haryana Agricultural University, Regional Research Station, Karnal, Haryana. To study the population fluctuation of pink stem borer during rabi 201516, maize inbred (HKI 1128) and hybrid (HQPM 1) were planted in a plot size of $20 \times 20 \mathrm{~m}$ with a spacing of $70 \times 20 \mathrm{~cm}$ in a randomized block design in three replications. None of the insecticide was sprayed and all other recommended agronomic practices were followed to raise the crop. Different stages of the pink stem borer (egg and different post embryonic development stages) were recorded at 7 days interval from October, 2015 to April, 2016. Observations were recorded from 20 plants uprooted from two rows of $2.5 \mathrm{~m}$ at 7 days interval. The observations were started 5 days after germination (DAG) of the crop. The sample were uprooted and brought to lab and dissected on the same day. Each stem was split open longitudinally from base to tip or vice-versa for recording different stages of the stem borer. Observations on infested plants and dead heart formation were also recorded.

Data on weather parameter such as temperature, relative humidity, sunshine hours and rainfall was obtained from meteorological observatory of Central Soil Salinity Research Institute (CSSRI), Karnal, Haryana. Correlations and regression analysis between $S$. inferens populations at different observation periods with different meteorological parameters were worked out using SPSS 16.0 version. The results have been discussed and interpreted in relation to the likely impact of weather parameters.

\section{RESULTS AND DISCUSSION}

Population dynamics: The results of the present investigations on population dynamics of pink stem borer, $S$. inferens on winter maize indicate that the moths

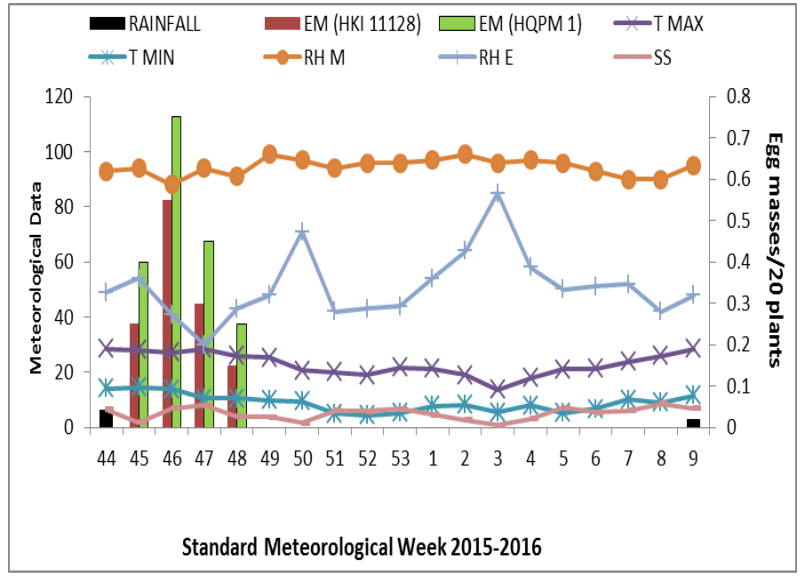

Fig. 1. Number of egg masses of $S$. inferens in relation to environmental factors during different standard weeks on maize genotypes (HKI 1128 and HQPM 1).

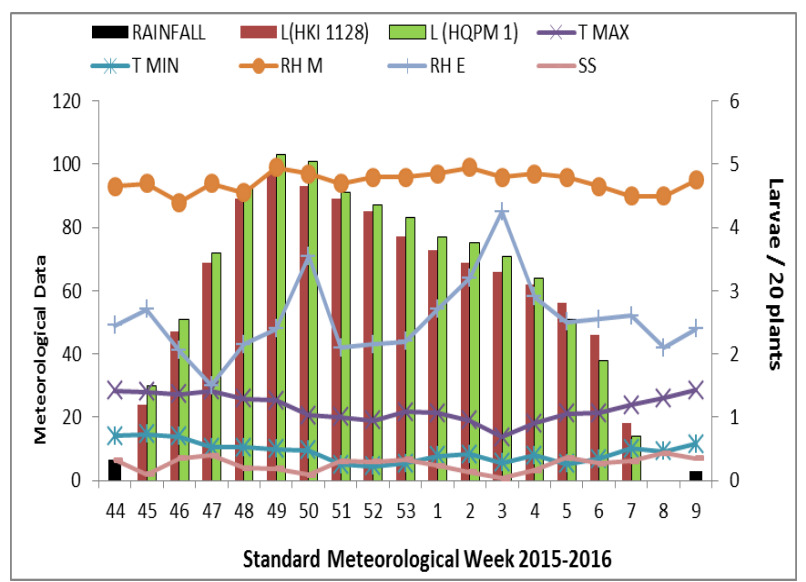

Fig. 2. Population of larvae of $S$. inferens in relation to environmental factors during different standard weeks on maize genotypes (HKI 1128 and HQPM 1).

of $S$. inferens started egg laying in the field during $45^{\text {th }}$ SW and continued to $48^{\text {th }} \mathrm{SW}$ (first to last week of November). The number of egg masses during the $45^{\text {th }}$ SW (first week of November) was low i.e. 0.25 egg masses/ 20 plants in HKI 1128 and 0.40/20 egg masses/20 plants in HQPM 1(Fig.1). During the $46^{\text {th }} \mathrm{SW}$, number of egg masses laid by females of $S$. inferens increased and reached to 0.55 and 0.75 egg masses/ 20 plants in HKI 1128 and HQPM 1, respectively. After this peak, a declining trend in density of egg masses per 20 plants was observed during $47^{\text {th }}$ and $48^{\text {th }} \mathrm{SW}$ i.e. 0.30 and 0.15 egg masses/ 20 plants on HKI 1128 and 0.45 and 0.25 egg masses/ 20 plants on HQPM 1, respectively. No egg masses was observed during $49^{\text {th }}$ SW and afterwards. Average number of egg masses was observed low in HKI 1128 as compared to HQPM 1 (Fig. 1).

No information is available on the correlation of egg masses of $S$. inferens and environmental factors in the literature. However, Joshi et al. (2009) reported that number of egg masses decreases with decrease in temperature in rice. Joshi et al. (2009) also reported that 
Hemant Sharma et al. / J. Appl. \& Nat. Sci. 9 (4): 1975 -1980 (2017)

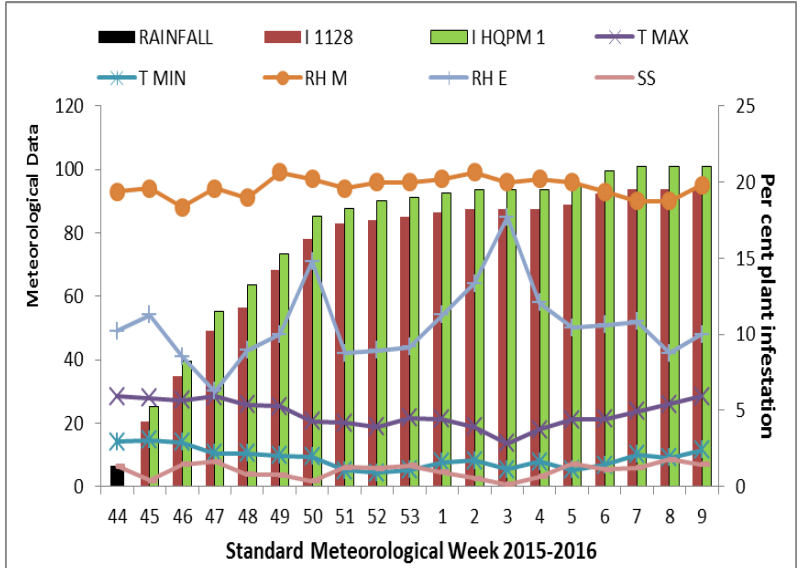

Fig. 3. Per cent plant infestation by Sesamia inferens in relation to environmental factors during different standard weeks on maize genotypes (HKI 1128 and HQPM 1).

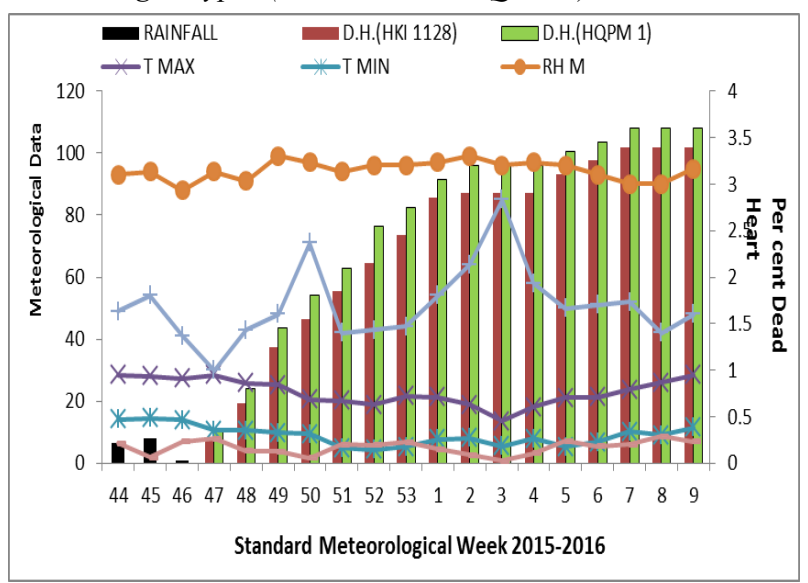

Fig. 4. Per cent dead heart formation by Sesamia inferens in relation to environmental factors during different standard weeks on maize genotypes (HKI 1128 and HQPM 1)

number of egg masses started decreasing from second and third week of October in rice and no egg masses was observed during fourth week of October and first week of November. However, in present studies the moths of $S$. inferens started egg laying in the maize field during first week of November and continued up to last week of November. It could be due to the factor that in rice adult female moth did not laid eggs as the crop stage was at maturity and pest might have migrated to wheat and winter maize.

Larval population of $S$. inferens on maize (Fig. 2) was reported from $45^{\text {th }} \mathrm{SW}, 2015$ to $7^{\text {th }} \mathrm{SW}, 2016$ (last week of October to first week of March). The larval density varied from 0 to $4.85 / 20$ plants on HKI 1128 and 0 to $5.15 / 20$ plants on HQPM 1 from $44^{\text {th }} S W$, 2015 to $9^{\text {th }}$ SW, 2016 (last week of October to first week of March). The average number of larvae was low in HKI 1128 as compared to HQPM 1. The average number of larvae was low i.e. 1.2/ 20 plants in HKI 1128 and 1.5/20 plants on HQPM 1 during 45 SW, 2015 (first week of November). Thereafter, the larval population increased gradually and reached to

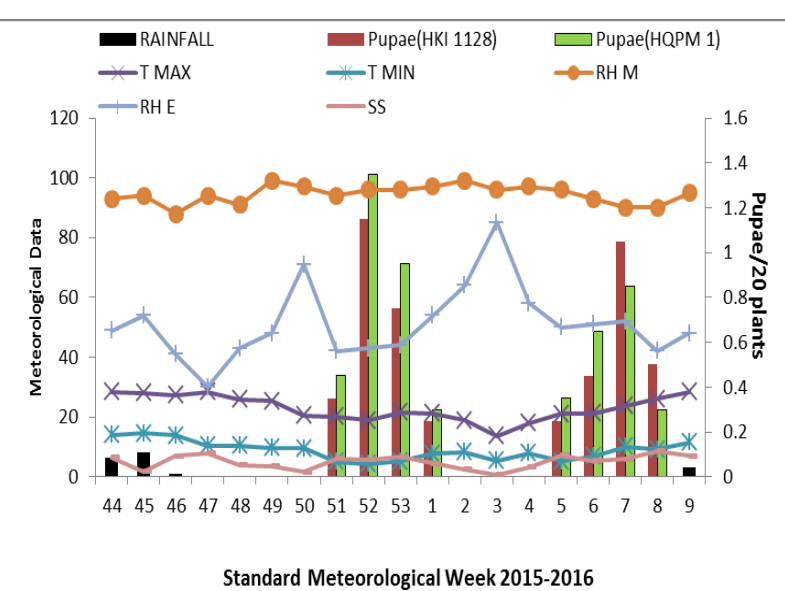

Fig. 5. Population of pupae of Sesamia inferens in relation to environmental factors during different standard weeks on maize genotypes (HKI 1128 and HQPM 1).

maximum of 4.85/ 20 plants on HKI 1128 and 5.15/ 20 plants on HQPM 1 during the $49^{\text {th }} \mathrm{SW}, 2015$. After this SW, number of larvae started decreasing. However, during the $2^{\text {nd }}, 3^{\text {th }}$ and $4^{\text {th }} \mathrm{SW}$ of 2016 larvae were not found infesting the crop because of the reason that it entered the hibernation. They were found singly or in groups in plant stem and dead hearts of maize. Diapause occurred in the sixth instar was facultative, induced by decrease in temperature. After $4^{\text {th }} \mathrm{SW}$ (last week of January), number of larvae started decreasing till $9^{\text {th }} \mathrm{SW}$ of 2016 in both maize genotypes i.e. HKI 1128 and HQPM 1 ( Fig. 2). The data indicate that the maximum larval population was occurred during last week of November and first week of December, afterwards average larval population decreased (Fig. 2). The infestation by $S$. inferens varied from 0 to 19.5 per cent in HKI 1128 and 0 to 21 per cent (Fig. 3) during $45^{\text {th }} \mathrm{SW}, 2015$ to $6^{\text {th }} \mathrm{SW}, 2016$ (last week of October to second week of February). The average dead heart formation by pink stem borer varied from 0 to 3.4 per cent in HKI 1128 and 0 to 3.6 per cent (Fig. 4) during $45^{\text {th }} \mathrm{SW}, 2015$ to $6^{\text {th }} \mathrm{SW}, 2016$ (last week of October to second week of February).No larval activity, per cent infestation and dead hearts of $S$. inferens was observed on maize during $2^{\text {th }} \mathrm{SW}$ to $4^{\text {th }} \mathrm{SW}$ of 2016 (Second week to last week of January). It could be due to the fact that insect might have entered the diapause (hibernation). No systematic information is available in literature regarding influence of weather parameters on incidence of $S$. inferens. However, Singh and Kular (2015) observed short peaks of $S$. inferens incidence on wheat crop during the months of December and February. Rahman and Khalequzzaman (2004) reported that $S$. inferens have the lower developmental threshold below $15^{\circ} \mathrm{C}$ because of which larval incidence decreased or no incidence was there. However, Garg (1988) reported that larvae of S. inferens remained dormant in winter and hibernated in rice stubbles from the end of October to March. 
Hemant Sharma et al. / J. Appl. \& Nat. Sci. 9 (4): 1975 -1980 (2017)

Table 1. Correlation of Sesamia inferens population with environmental factors on maize genotypes (HQPM 1 and HKI 1128).

\begin{tabular}{llllll}
\hline Weather parameter & Egg masses & Larvae & Pupae & Infested plants & Dead Hearts \\
\hline HKI 1128 & & & & & $-0.5455^{*}$ \\
\hline Temperature (maximum) & $0.4980^{*}$ & $-0.4992^{*}$ & -0.2132 & $-0.6060^{*}$ & $-0.6353^{*}$ \\
Temperature (minimum) & $0.5763^{*}$ & $-0.5183^{*}$ & $-0.4796^{*}$ & $-0.7531^{*}$ & 0.2438 \\
Relative humidity (\%) M & $-0.5317^{*}$ & $0.5042^{*}$ & -0.1875 & 0.2996 & 0.3207 \\
Relative humidity (\%) E & -0.3753 & 0.0974 & -0.2503 & 0.2388 & 0.0544 \\
Sun shine hours & 0.1534 & -0.3889 & 0.3723 & 0.0058 & $-0.5114^{*}$ \\
Rainfall (mm) & 0.2307 & $-0.5698^{*}$ & -0.2996 & $-0.7465^{*}$ & $-0.5781^{*}$ \\
\hline HQPM 1 & & & & & $-0.6690^{*}$ \\
\hline Temperature (maximum) & $0.5150^{*}$ & $-0.4872^{*}$ & -0.2851 & $-0.5940^{*}$ & 0.2746 \\
Temperature (minimum) & $0.5890^{*}$ & $-0.4717^{*}$ & $-0.5781^{*}$ & $-0.7412^{*}$ & 0.3280 \\
Relative humidity (\%) M & $-0.5249^{*}$ & $0.5202^{*}$ & -0.0678 & 0.2858 & 0.0361 \\
Relative humidity (\%) E & -0.3805 & 0.1343 & -0.2556 & 0.2338 & $-0.5357^{*}$ \\
Sun shine hours & 0.1318 & -0.4377 & 0.3386 & 0.0021 & $-0.7480^{*}$ \\
Rainfall (mm) & 0.2594 & $-0.5242^{*}$ & -0.3018 & & \\
\hline
\end{tabular}

*Significant at $\mathrm{P}=0.05$

Table 2. Multiple regression analysis between Sesamia inferens population and environmental factors on maize genotypes (HQPM 1 and HKI 1128).

\begin{tabular}{|c|c|c|}
\hline HKI 1128 & Regression equations & $\mathbf{R}^{2}$ \\
\hline EGG MASSES & $\mathrm{Y} 5=5.145-0.077 \mathrm{X} 1+0.121 \mathrm{X} 2-0.031 \mathrm{X} 3-0.033 \mathrm{X} 4-0.033 \mathrm{X} 5-0.006 \mathrm{X} 6$ & 0.59 \\
\hline LARVAE & $\mathrm{Y} 2=3.781-0.041 \mathrm{X} 1-0.072 \mathrm{X} 2+0.116 \mathrm{X} 3-0.124 \mathrm{X} 4-0.735 \mathrm{X} 5-0.348 \mathrm{X} 6$ & 0.82 \\
\hline PUPAE & $\mathrm{Y} 4=6.079-0.007 \mathrm{X} 1-0.093 \mathrm{X} 2-0.049 \mathrm{X} 3-0.005 \mathrm{X} 4+0.017 \mathrm{X} 5+0.037 \mathrm{X} 6$ & 0.48 \\
\hline INFESTED PLANTS & $\mathrm{Y} 1=-2.451+0.198 \mathrm{X} 1-0.315 \mathrm{X} 2+0.003 \mathrm{X} 3+0.064 \mathrm{X} 4+0.084 \mathrm{X} 5-0.248 \mathrm{X} 6$ & 0.75 \\
\hline DEAD HEART & $\mathrm{Y} 3=-7.369+0.151 \mathrm{X} 1-0.289 \mathrm{X} 2+0.014 \mathrm{X} 3+0.107 \mathrm{X} 4+0.361 \mathrm{X} 5-0.108 \mathrm{X} 6$ & 0.65 \\
\hline \multicolumn{3}{|c|}{ 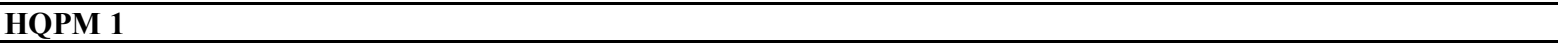 } \\
\hline EGG MASSES & $\mathrm{Y} 10=5.987-0.075 \mathrm{X} 1+0.122 \mathrm{X} 2-0.037 \mathrm{X} 3-0.026 \mathrm{X} 4-0.059 \mathrm{X} 5-0.0018 \mathrm{X} 6$ & 0.61 \\
\hline LARVAE & $\mathrm{Y} 7=2.612-0.0513 \mathrm{X} 1-0.0414 \mathrm{X} 2+0.136 \mathrm{X} 3-0.131 \mathrm{X} 4-0.797 \mathrm{X} 5-0.361 \mathrm{X} 6$ & 0.80 \\
\hline PUPAE & $Y 9=6.201-0.015 \mathrm{X} 1-0.1145 \mathrm{X} 2-0.0425 \mathrm{X} 3-0118 \mathrm{X} 4+0.004 \mathrm{X} 5+0.0612 \mathrm{X} 6$ & 0.58 \\
\hline INFESTED PLANTS & $\mathrm{Y} 6=-1.781+0.223 \mathrm{X} 1-0.341 \mathrm{X} 2-0.0059 \mathrm{X} 3+0.0672 \mathrm{X} 4+0.064 \mathrm{X} 5-0.269 \mathrm{X} 6$ & 0.74 \\
\hline DEAD HEART & $\mathrm{Y} 8=-7.759+0.148 \mathrm{X} 1-0.309 \mathrm{X} 2+0.022 \mathrm{X} 3+0.1077 \mathrm{X} 4+0.363 \mathrm{X} 5-0.118 \mathrm{X} 6$ & 0.67 \\
\hline
\end{tabular}

$\mathrm{X} 1$ = Temperature (maximum), X2 = Temperature (minimum), X3 = Relative humidity (morning), X4 = Relative humidity (evening), X5 = Sun shine hours, X6 = Rainfall $(\mathrm{mm})$

The data on pupal density indicate that there were two peaks of population of pupae i.e. one during $52^{\text {nd }} \mathrm{SW}$ and the second during $7^{\text {th }} \mathrm{SW}$. The pupal density varied from 0 to $1.15 / 20$ plants on HKI 1128 and 0 to $1.35 / 20$ plants from $44^{\text {th }} \mathrm{SW}, 2015$ to $9^{\text {th }} \mathrm{SW}, 2016$ (last week of October to first week of March). The average number of pupae was low in HKI 1128 as compared to HQPM 1 (Fig. 5). The larvae reached near maturity and changed to pupae in the $51^{\text {st }} \mathrm{SW}$ of 2015. Thereafter, the population of pupae increased and reached to maximum of $1.15 / 20$ plants on HKI 1128 and $1.35 / 20$ plants in HQPM 1 during the $52^{\text {th }}$ SW, 2015. After this, number of pupae started decreasing till $1^{\text {st }} \mathrm{SW}$ of 2016 . However, during the $2^{\text {th }}, 3^{\text {th }}$ and $4^{\text {th }} \mathrm{SW}$ of 2016 pupae were not found in the crop (HKI 1128 and HQPM 1) because of the reason that larvae entered the hibernation. The number of pupae started increasing again from $5^{\text {th }} \mathrm{SW}$ of 2016 in both maize genotypes (HKI 1128 and HQPM 1). Thereafter, the population of pupae increased gradually and reached to $1.05 / 20$ plants in HKI 1128 and $0.85 / 20$ plants in HQPM 1 during the $7^{\text {th }} \mathrm{SW}, 2016$ (Fig. 5). After this period of observation, number of pupae started decreasing and no pupae observed during on $9^{\text {th }}$ SW of 2016 in both maize genotypes (HKI 1128 and
HQPM 1). The data indicate that there were two peaks of population of pupae during rabi maize. Tripathi and Ram (1969) reported that the hibernating larva of pink stem borer pupated in the first week of February and moths emerged in late February give support to the present findings.

Impact of weather on pest activity: Different environmental variables seemed to affect $S$. inferens population in different ways. S. inferens egg masses had a significant positive correlation with maximum temperature (Tmax.) and minimum temperature (Tmin.) and had a significant negative correlation with Relative humidity (Morning) $(\mathrm{RHm})(\mathrm{r}=0.4980,0.5763$ and $0.5317)$ on HKI 1128 and $(r=0.5150,0.5890$ and 0.5249 ) on HQPM 1, respectively (Table 1). No information is available on the correlation of egg masses of $S$. inferens and environmental factors in the literature. However, Joshi et al. (2009) reported that number of egg masses decreases with decrease in temperature in rice. The larvae of $S$. inferens was correlated with abiotic factors (meteorological) it was found that larval population had a significant negative correlation with maximum temperature (Tmax.) and minimum temperature (Tmin.) $(\mathrm{r}=-0.4992,-0.5183)$ on HKI 1128 and( $\mathrm{r}=$ $-0.4872,-0.4717$ ) on HQPM 1 , respectively (Table 2). 
Joshi et al. (2009) reported a significant negative correlation with maximum and minimum temperatures $(\mathrm{r}$ values $=-0.543$ and -0.878). However, Singh and $\mathrm{Ku}-$ lar (2015) reported negative correlation was observed between the incidence of pink stem borer and maximum temperature and minimum temperature ( $\mathrm{r}$ values $=-0.19$ and -0.005). The larval population of $S$. inferens in the present investigations, had a significant positive correlation with Relative humidity (Morning) (RHm) $(\mathrm{r}=0.5042)$ on HKI 1128 and $(\mathrm{r}=0.5202)$ on HQPM 1 (Table 1). Likewise, positive effect of relative humidity $(\mathrm{r}=0.53)$ on population build up of this pest has been reported by Singh and Kular (2015).

In the present investigations, the pest had significant negative correlation with rainfall $(\mathrm{r}=-0.5698$ on HKI 1128 andr $=-0.5242$ on HQPM 1). Likewise, negative effect of rainfall on population buildup of this pest has been reported by Bhatnagar and Saxena (1999) and Rai et al. (2002). However, Isahaque and Rahman (1983) reported positive effect of rainfall on population buildup of this pest. In the present studies, data on larvae of $S$. inferens was correlated with sun shine hours (SSH) it was found that larval population had a negative correlation with sun shine hours ( $\mathrm{SSH}$ ) and rainfall (RF) $(r=-0.3889)$ on HKI 1128 and $(r=-0.4377)$ on HQPM 1, respectively. However, Isahaque and Rahman (1983) did not find any effect of sunshine hours on the population of borers.

In the present studies, a significant negative correlation between pupae and minimum temperature (Tmin.) ( $\mathrm{r}=$ -0.4796 on HKI 1128 andr= -0.5781 on HQPM 1) was observed. However literature is silent, on the correlation of population of pupae of $S$. inferens and environmental factors. It was further observed in the present studies that a significant negative correlation was worked out between per cent infested plants and maximum temperature (Tmax.) and minimum temperature (Tmin.), rainfall (RF) $(\mathrm{r}=-0.6060,-0.7531$ and $0.7465)$ on HKI 1128 and $(\mathrm{r}=-0.5940,-0.7412$ and 0.7480 ) on HQPM 1, respectively. There was also significant negative correlation between dead hearts and maximum temperature (Tmax.) and minimum temperature (Tmin.), rainfall (RF) $(\mathrm{r}=-0.5455,-0.6353$ and $0.5114)$ on HKI 1128 and $(\mathrm{r}=-0.5781,-0.6690$ and 0.5357 ) on HQPM 1, respectively. No information is available in literature on the correlation of pupae and dead hearts of $S$. inferens and environmental factors.

Multiple regression analysis: The multiple regression analysis, which explained the average relationship between $S$. inferens and weather parameter i.e. the trend of changes in $S$. inferens population per unit change in weather parameters, indicated that there was also significant 59 per cent and 61 per cent (regression equation $\mathrm{Y} 1$ and $\mathrm{Y} 6)$ contribution of these factors $\left(\mathrm{R}^{2}=\right.$ 0.59 in HKI 1128 and $R^{2}=0.61$ in HQPM 1) for variability in egg masses (Table 2). Out of 59 per cent (HKI 1128 ) and 61 per cent (HQPM1) variability in pink stem borer egg masses due to various abiotic factors, maximum temperature (Tmax.) and minimum temperature (Tmin.), relative humidity (morning) accounted for 46 per cent (HKI 1128) and 45 per cent (HQPM 1) variability (regression equation - Y1 and Y6) and these were the most important factors affecting egg masses. There was also significant 75 per cent and 74 per cent (regression equation Y2 and Y7) contribution of these factors $\left(\mathrm{R}^{2}=0.82\right.$ in HKI 1128 and $\mathrm{R}^{2}=0.80$ in HQPM 1) for variability in larval population (Table 2). Out of 82 per cent (HKI 1128) and 80 per cent (HQPM1) variability in pink stem borer larval population due to various abiotic factors, maximum temperature (Tmax.) and minimum temperature (Tmin.), rainfall (RF), relative humidity (morning) accounted for 51 per cent (HKI 1128) and 48 per cent (HQPM 1) variability (regression equation-Y2 and Y7) and these were the most important factors affecting pink stem borer abundance (Table 2).

It was found that for total variability in pupae contribution by abiotic factors (meteorological) was 48 per cent and 58 per cent (regression equation $\mathrm{Y} 3$ and $\mathrm{Y} 8$ ) $\left(\mathrm{R}^{2}=0.48\right.$ in HKI 1128 and $\mathrm{R}^{2}=0.58$ in HQPM 1) (Table 2). Out of 48 per cent (HKI 1128) and 58 per cent (HQPM1) variability in pink stem borer pupae due to various abiotic factors, minimum temperature (Tmin.) accounted for 22 per cent (HKI 1128) and 33 per cent (HQPM 1) variability (regression equation Y3 and Y8) and these were the most important factors affecting pupae.

There was also significant 75 per cent and 74 per cent (regression equation Y4 and Y9) contribution of these factors $\left(\mathrm{R}^{2}=0.75\right.$ in HKI 1128 and $\mathrm{R}^{2}=0.74$ in HQPM 1) for variability in per cent infested plants (Table 2). Out of 75 per cent (HKI 1128) and 74 per cent (HQPM1) variability in per cent infested plants due to various abiotic factors, maximum temperature (Tmax.) and minimum temperature (Tmin.), relative humidity (morning) accounted for 66 per cent (HKI 1128) and 65 per cent (HQPM 1) variability (regression equation - Y4 and Y9) and these were the most important factors affecting per cent infested plants. There was also significant 65 per cent and 67 per cent (regression equation Y5 and Y10) contribution of these factors $\left(R^{2}\right.$ $=0.65$ in HKI 1128 and $\mathrm{R}^{2}=0.67$ in HQPM 1) for variability in dead hearts (Table 2). Out of 65 per cent (HKI 1128) and 67 per cent (HQPM1) variability in pink stem borer dead hearts due to various abiotic factors, maximum temperature (Tmax.) and minimum temperature (Tmin.), relative humidity (morning) accounted for 41 per cent (HKI 1128) and 46 per cent (HQPM 1) variability (regression equation - Y5 and Y10) and these were the most important factors affecting dead hearts. Joshi et al. (2009) reported that density of egg masses declined after with decrease in temperature and a negative correlation of the total larvae with maximum temperature, minimum temperature 
and evening relative humidity and a positive correlation was observed between the mortality of larvae and maximum temperature, sunshine hours while it was negative with morning relative humidity. Velasco et al. (2007) also reported that there is a clear relationship between altitude of locality and abundance of the borer. Population of the borer has a significant relationship with the temperature parameters.

This study generated valuable data on the population dynamics of this pest which is one of the most important pests of maize. The data so generated would help in the forecast about it likely incidence on the basis of prevailing weather and shall also prove helpful in devising a coherent strategy for its management.

\section{Conclusion}

The information on population dynamics of any insect pest in a given ecological niche should be considered as starting point for evolving eco- friendly pest management package. It is an established fact that population dynamics of any insect is greatly influenced by weather fluctuations and thereby the location specific studies become more imperative. Although study of population dynamics of this study were conducted elsewhere but this is first study of its kind in the state of Haryana. The number of egg masses laid by females of $S$. inferens increased and reached to 0.55 and 0.75 egg masses/ 20 plants during the $46^{\text {th }} \mathrm{SW}$, in HKI 1128 and HQPM 1, respectively. The larval density varied from 0 to $4.85 / 20$ plants on HKI 1128 and 0 to 5.15/20 plants on HQPM 1 from $44^{\text {th }} \mathrm{SW}, 2015$ to $9^{\text {th }} \mathrm{SW}$, 2016 (last week of October to first week of March). No larval activity, per cent infestation and dead hearts of $S$. inferens was observed on maize during $2^{\text {th }} \mathrm{SW}$ to $4^{\text {th }} \mathrm{SW}$ of 2016 (Second week to last week of January). It could be due to the fact that insect might have entered the diapause (hibernation). The population dynamics revealed by this study has far reaching significance in pest management strategy as integrated control measures may be focused only during the period wherein population exceeds economic threshold level (ETL).

\section{REFERENCES}

Anonymous. (2014). Statistical Abstract of Haryana. Published by Department of Economic and Statistical Analysis, Haryana, 2014. pp. 239, 242 and 252

Bhatnagar, A and Saxena, R. (1999). Environmental correlates of population build up of rice insect pests through light trap catches. Oryza, 36: 241-245

Bhattacharya, D.P. (1976). On occurrence of the stem borer
Sesamia inferens (Walker) (Insecta; Lepidoptera: Noctuidae) in the Andaman Islands (together with its host range of cultivated crops in the mainland of India). Newsletter Zoological Survey of India,2(3): 105

Chatterji, S. M., Young, W. R., Sharma, G. C., Sayi, I. V., Chahal, B. S., Khare, B. P., Rathore, Y. S., Panwar V. P. S. and Siddiqui, K. H. (1969). Estimation of loss in yield of maize due to insect pests with special reference to borers. Indian J. Ent., 3(2): 109-115

Garg, D. K. (1988). Host range and overwintering of rice pink stem borer in a hilly region of India. Int.Rice Res. Newsletter, 13: 23-24

Isahaque, N. M. and Rahaman, M. (1983). Seasonal incidence of rice stem borer, Tryporyza incertulas Walker in Assam. Pesticides, 17: 25-27

Joshi, G., Ram, L. and Singh, R. (2009). Population dynamics of paddy stem borers in relation to biotic and abiotic factors. Annals of Biol., 25: 47-51

Rahman, M. T. and Khalequzzaman, M. (2004). Temperature requirements for the development and survival of rice stem borers in laboratory conditions. Entomolgia Sinica, 11: 47-60

Rai, A. K., Singh, A. K. and Khan, M. (2002). Influence of weather factors on light trap catches of yellow stem borer in Kharif season. Indian J. Ent.,64(4): 510-517

Rajagopal, D. and Channabasavanna, G.P. (1975). Insect pests of maize in Karnataka. Mysore J. Agri. Sci., 9(1): 110-121

Rao, S., Venugopal, C. N. and Razvi, S.A. (1983). Parasitism, a key factor in checking rice pest population. Entomon, 8: 97-100

Sajjan, S. S., Sekhon, S. S. and Kanta, U. (1986). Occurrence of insect pests on winter maize in Punjab. J. Res., Punjab Agricultural University, Ludhiana, 23(3):451-454

Siddiqui, K. H. and Marwaha, K. K. (1993). The vistas of Maize Entomology in India. Kalyani Publishers, New Delhi. p 184

Singh, B. and Kular, J. S. (2015). Incidence and management of pink stem borer (Sesamia inferens) in rice-wheat cropping system. J. Insect Sci., (Sp.): 142-145

Teetes, G. L., Seshureddy, K. V., Leuschner, K. and House, L. R. (1983). Sorghum insect identification handbook, Information Bulletin No. 12, Patancheru, Andra Pradesh -502324, India. International Crops Research Institute for the Semi-Arid Tropics, $\mathrm{p} 124$

Tripathi, R. L. and Ram, S. (1969). Notes on stem borer hibernating in the stubbles of different varieties of rice Oryza sativa L. Indian J. Agri. Sci., 39: 860-861

Upadhyaya, V. K., Mishra, B. N. and Yadav, U. S. (1991). Insect pests of rabi maize preventing their proliferation. Indian Farming, 41 (4):27-28

Velasco, P., Revilla, P., Monetti, L., Butron, A., Ordas, A. and Malvar, R.A.(2007). Corn borers (Lepidoptera: noctuidae; crambidae) in northwestern spain: population dynamics and distribution. Maydica,52:195-203 